Portland State University

PDXScholar

8-6-1975

\title{
The Effects of an Innovative Curriculum on the Attitudes of "Educationally Disadvantaged" Freshman College Students
}

Julius William Wilkerson

Portland State University

Follow this and additional works at: https://pdxscholar.library.pdx.edu/open_access_etds

Part of the Higher Education Commons, and the Psychology Commons Let us know how access to this document benefits you.

Recommended Citation

Wilkerson, Julius William, "The Effects of an Innovative Curriculum on the Attitudes of "Educationally Disadvantaged" Freshman College Students" (1975). Dissertations and Theses. Paper 2388.

https://doi.org/10.15760/etd.2384

This Thesis is brought to you for free and open access. It has been accepted for inclusion in Dissertations and Theses by an authorized administrator of PDXScholar. Please contact us if we can make this document more accessible: pdxscholar@pdx.edu. 
AN ABSTRACT OF THE THESIS OF Julius William Wilkerson for

the Master of Science in Psychology presented August 6, 1975.

Title: The Effects of an Innovative Curriculum on the Attitudes of

"Educationally Disadvantaged" Freshmen College Students.

APPROVED BY MEMBERS OF THE THESIS COMMITTEE:

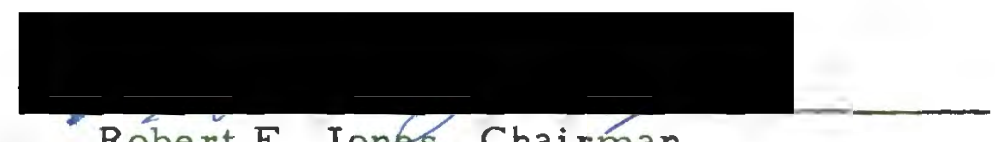

Robert E. Jones, Chairman

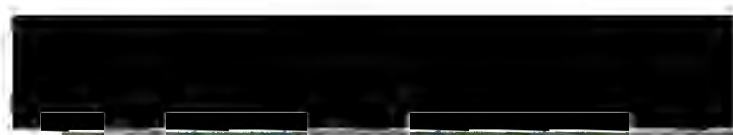

Hugo Mayna rd

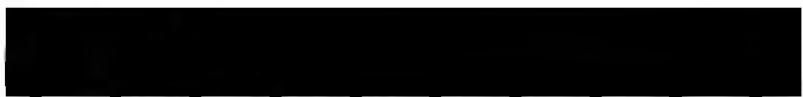

Morris Weitman

Educational research literature suggests the expectations for success in college for youth from "educationally disadvantaged" backgrounds are tragically small. Reasons offered for this have included the lack of requisite academic preparation, lack of motivation, lack of appreciation for the value of a college education. The general purpose of this study was to investigate the effectiveness of an innovative instructional technique in promoting the development of positive attitudes about self-worth, and academic achievement, for "disadvantaged" students. Specifically, this study attempted to 
identify the structure of attitudes of "educationally disadvantaged" students in the Portland State University support service program (Operation PLUS) about concepts which a re related to academic skills, academic achievement and self-worth, after one year of college experience. The following experimental hypothesis was tested: Students in the Operation PLUS Innovative Curriculum (IC) will show a positive attitude pattern greater, as measured on a semantic differential type rating scale, than the pattern shown by the students in the PLUS standard curriculum (PSC).

Fifty-four students were admitted to begin studies at Portland State University as entering freshmen in the Operation PLUS program, the University's special admission and support program for educationally and economically "disadvantaged" students. Half (27) of these students served as the Operation PLUS Standard Curriculum Group and took 12 hours of the University's standard lower-division course work, one hour of P.E. and the Operation PLUS orientation course, for a total of 16 hours. The other 27 Operation PLUS students served as Operation PLUS Innovative Curriculum Group (OPICG) and were given the innovative curriculum (12 hours), one hour of P.E. and the same course in Orientation taken by the Operation PLUS Standard Curriculum Group for a total of 16 hours. A group of 54 regularly admitted entering freshmen at Portland State University was drawn on a random basis, then half of these (27) 
were randomly selected to serve as the Regular University Curriculum Group (UCG). Unlike PLUS's "disadvantaged" students, this group met regular University admission requirements of a minimum 2.25 G. P.A. in high school. Also, in contrast to the PLUS student groups, this group of students had a socio-economic status high enough to preclude their receiving financial aid from the University. This group was used to explore the nature of the instrument used in the study.

A semantic differential-type rating scale was developed and utilized as the attitude-measuring instrument in this study. To calibrate the scale in terms of the positive direction and negative direction of the scale, a group of 27 persons ranging in age from 21 to 33 were chosen from the Portland Model Cities District (The Model Cities District is the area, federally defined as "substandard", in the Northeast area of Portland, Oregon, where the highest concentration of the city's 21,000 blacks and other minority group members live.) These persons were asked to rate 21 concepts, divided into three classifications: self-worth, academic skills, and academic orientation. It was assumed that the se persons had been classified as educationally "disadvantaged" at one point in their lives, but had achieved educational success. They were persons considered successful in occupations that demand a certain level of selfconfidence as well as having mastered and continued the use of 
certain academic skills. This group, then, served as the Criterion Group (CG) for the two student comparison groups who took the test at the end of the school year, in the sense that a positive pattern in attitude for each of the student groups was determined on the basis that the pattern was in the direction shown by this group.

Each of the semantic differential tests taken by the subjects in the two student groups was scored on the basis of the cumulative points per scale. A mean score was then calculated for each of the three classifications. The mean scores in the two groups we re compared using the Hoteling's T-square.

The results did not support the experimental hypothesis; subjects in the PLUS innovative curriculum did not show a more positive attitude pattern than the subjects in the PLUS standard curriculum on the three scales: self-worth, academic skills and academic orientation. However, the results do indicate that the innovative curriculum did have a positive effect on the students' attitudes about self-worth, academic skills and orientation. 
THE EFFECTS OF AN INNOVATIVE CURRICULUM ON THE ATTITUDES OF "EDUCATIONALLY DISADVANTAGED"

FRESHMEN COLLEGE STUDENTS

by

JULIUS WILLIAM WILKERSON

A thesis submitted in partial fulfillment of the requirements for the degree of

\author{
MASTER OF SCIENCE \\ in \\ PSYCHOLOGY
}

Portland State University

1975 
TO THE OFFICE OF GRADUATE STUDIES AND RESEARCH:

The members of the Committee approve the thesis of Julius William Wilkerson presented August 6, 1975.
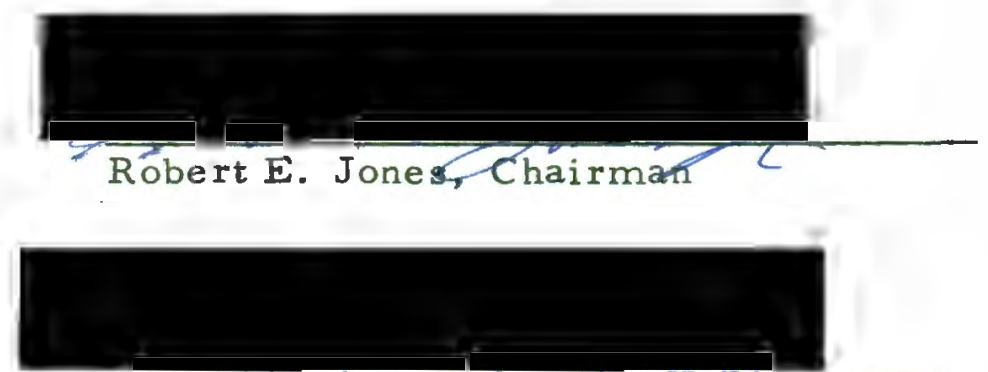

Hugo Naynard

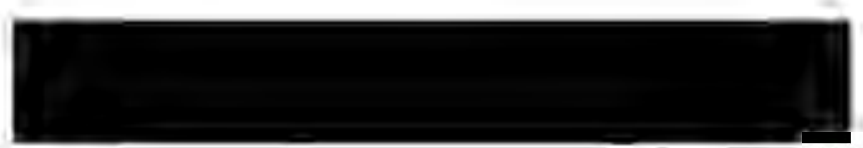

Morris Weitman

\section{APPROVED:}
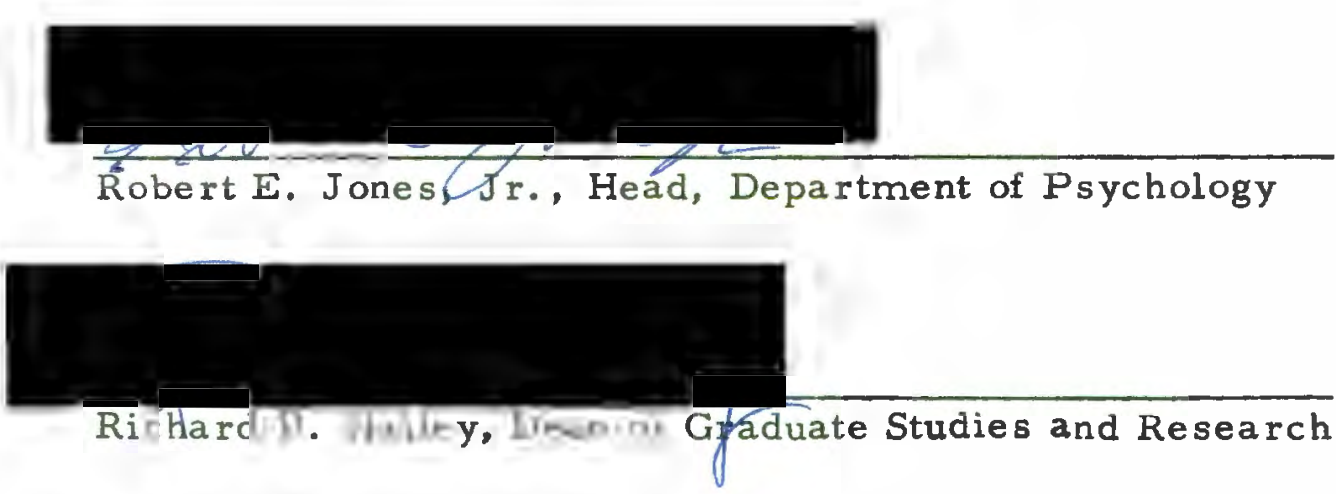

August 6,1975 


\section{ACKNOWLEDGEMENTS}

It is with pleasant responsibility that I express my gratitude and appreciation to those who have contributed to the development of this study in higher education. I am particularly grateful to Dr. Hugo Maynard, Dr. Larry Stewart and Dr. Glen Murphy, the Portland State University faculty members who were the nucleus of the curriculum development team for the special courses, and the teachers of those classes. Their scholarly and human concern for the students for which this curriculum was developed and their devotion of time and energy helped make this study a success. I am grateful to

George C. Hoffmann, Dean of the College of Social Science, Karl Dittmer, Dean of the College of Science, and William Hamilton, Dean of the College of Arts and Letters. Their cooperation made this experiment possible.

I am also grateful to Robert Jones, my thesis committee Chairman. His comments and criticisms helped in the development and procedures of this study.

I thank Morris Weitman, one of my thesis committee members, who gave freely of his time. His assistance with the evaluation design of the study was invaluable. I am also grateful to him for his good-humored patience. At times when my own spirits were lowered by the thought of daily tasks to be done and my thesis lying accusingly 
unfinished, his encouraging comments buoyed my perseverance and removed the guilt of procrastination which made the task more arduous.

Professor James A. Paulson, whose judgement and assistance with the statistical data has been of great value to this study, deserves special thanks.

I am specifically grateful to the Operation PLUS students for their trust in me and their cooperation with me in producing this study, the first in higher education for educationally "disadvantaged" students at Portland State University. I appreciate, too, the cooperation of the regular student body faculty, and the community participants. Caroline Stevenson has typed the final draft of the thesis with a high degree of skill and care; she has my thanks. 
CHAPTER

The Problem $\ldots \ldots \ldots \ldots \ldots \ldots \ldots, 1$

Curriculum Development at Other

Institutions ............... 4

The Operation PLUS Program ....... 8

Motivation in Relation to the Valuation of

Concepts Used in the Study ......... 11

Attitude Measurement $\ldots \ldots \ldots \ldots \ldots \ldots, 14$

II PROCEDURE $\ldots \ldots \ldots \ldots \ldots \ldots \ldots \ldots \ldots \ldots \ldots$

Methods - Part I .............. 16

Subjects

Scale Construction

Methods - Part II .............. 20

Treatment

Procedure for Scoring Semantic Differential 


\section{INT RODUCTION}

The purpose of this study was to investigate the effectiveness of a culturally, socially and academically relevant, problem-solving type curriculum in promoting positive self-worth and positive attitudes about academic achievement in a group of first-year, educationally

"disadvantaged" students at Portland State University. A statement of the problem of the "disadvantaged" student is presented first in order to acquaint the reader with the Federal Government's view of the educational condition of these students. Second, a review of what has been done in curriculum development for the "disadvantaged" student at other institutions. Third, an overview of the Operation PLUS program at Portland State University. Fourth, an overview of the motivational aspect of the experimental curriculum as it relates to student valuation of concepts used in the study. Fifth, a consideration of the methodology regarding attitude measurement is presented.

\section{THE PROBLEM}

In the decade of the $1960^{\prime} \mathrm{s}$, two deliberate social policies 


\section{LIST OF TABLES}

TABLE

PAGE

I Concepts on the Semantic Differential

Scale $\ldots \ldots \ldots \ldots \ldots \ldots \ldots \ldots, 18$

II Comparison Groups' Characteristics and

Aspects of Treatment $\ldots \ldots \ldots \ldots \ldots, \quad 22$

III Mean Scores Between Groups .......... 23

IV Correlations Between Measures .......... 24 
brought new post-secondary educational opportunities to millions of high school graduates. First, local, state and Federal governments reduced the cost barrier by offering subsidies to students and by building and subsidizing low-tuition institutions. Second, some educational institutions reduced the barrier of selective admissions by lowering or abandoning requirements for high academic performance in high school and on standardized achievement tests.

As a result, the generation now beginning their post-secondary education includes a significant portion of students who lack abilities traditionally assumed for college students. Typically, they lack the confidence as well as the skills essential for advanced academic work as it is now designed. The pattern for many of these students has been one of a revolving door: they enter college and leave within the year without fulfilling their educational goals.

For such students, access to further education does not guarantee a fair chance of reaping the traditional benefits of that experience. Thus, post-secondary institutions now face a broader social purpose. They must create conditions for effective learning for a more diverse range of post-secondary students.

The efforts of post-secondary educational institutions to respond to students who lack traditional academic skills have taken two basic forms. Substantial numbers of institutions have initiated programs of recruitment and transition to college aimed at improving access 
and preparing students for college work. Also, many institutions have strengthened their counseling, tutorial and other support services in order to improve the retention of students. With the help of these programs, some students have been able to compete on successful terms with other students in traditional courses. In the latter case, representing one approach, it is the student who has adapted to the institution's standards and learned to cope with the traditional processes of teaching and learning within the se institutions.

Another alternative pursued by institutions has been to adopt basic processes of teaching to the styles of learning most appropriate to the students it serves. Attempts to do this may incorporate counselling, tutoring and other services within an overall educational approach. But, they rely primarily upon altering or expanding the setting, content and methods for teaching and learning.

According to the Task Force on the Disadvantages and PostSecondary Education (H.E. W. ) both approaches are necessary to redress the growing mismatch between post-secondary institutions and the students entering them today. While both efforts assume that these students need to acquire essential skills to continue their learning, successful efforts of either kind are likely to recognize that the mere acquisition of skills will not compensate for years of merely adequate or marginal performance as students. Equally important is an underlying disposition to apply skills in the pursuit of 
educational goals. Even more than other students, the disadvantaged students need to learn how to learn. The learning to learn involves not only academic skills but attitudes, aspirations and the experience of success (Educational Task Force Report, 1971).

What is required for effective learning, and how is this achieved for various students in different settings? These two questions probe the frontiers of research, while successful responses to these new students is a task of major national importance (Office of Education, H. E. W., 1974). The office of Education invited post-secondary institutions which could demonstrate success in promoting effective learning for low-achieving students to participate in the national effort to address the problem.

\section{CURRICULUM DEVELOPMENT AT OTHER INSTITUTIONS}

According to a publication by the Western Interstate Commission for Higher Education (WICHE), 160 institutions in the U.S. had replied to its 1969 survey requesting information about what was being done at their institution to meet the needs of minority groups. Fewer than ten indicated that they had no programs aimed at bringing the benefits of education to minority groups. (WICHE, 1969)

Most of the minority-oriented programs fell into the category called "College Readiness Programs" or "Educational Opportunity 
Programs." These programs basically were college preparation programs. They attempted to prepare academically deprived minority members for entering college on an equal footing with students from middle-class oriented homes.

A National Conference on Higher Education of the Disadvantaged, sponsored by the Office of Educational Opportunity (Division of Research and Demonstration) and the Experiment in Higher Education of Southern Illinois University was held in Washington, D. C., March 14-16, 1968. This was the first conference of its kind held in this nation and it represented a growing recognition and national concern with the need for providing equal educational opportunities for lowincome, "disadvantaged" youth on the part of American Colleges and Universities. It was the information disseminated from that conference that inspired investigation and then the initiation of this study. The aim of the conference was to promote a vigorous dialogue between the administrators and faculty members of Higher Education about the "Problems-Progress-Prospects" of developing programs of higher education for the disadvantaged. Some of the major issues that were identified and formulated included:

1. The underlying need and philosophy of "experimental" programs in Higher Education for the "disadvantaged".

2. The nature and scope of curriculum innovations essential to making Higher Education more accessible, relevant and viable to and for Higher Education for the "disadvantaged". 
3. Prospects for replicating and expanding programs of Higher Education for the "disadvantaged" and strategies for institutionalizing such programs in colleges and universities.

Southern Illinois University (S.I.U.) and Antioch College in southwestern Ohio appeared to be making the boldest approaches to addressing the curriculum issue regarding higher education for the "disadvantaged" and leading the race of the few colleges and universities working on curriculum innovation and experimentation. Both of these institutions were developing what they called an "organic method"for education which stresses an inductive, problem-solving approach to the learning process. In brief, this means that the development of curriculum and the design of courses and methods of instruction proceeds in the context of an educational process. The students involved are actually engaged in the direct observation and application of information, knowledge and skills, in the actual community.

This approach to meeting the educational needs of disadvantaged students appealed to the interest of the writer for two basic reasons. First, as the Director of the Support Service Program (Operation PLUS) at Portland State University, the writer had direct exposure and understanding of the shortcomings of the remedial courses designed to help students make up deficiencies. One problem with such courses is they do not, and probably cannot, in view of the 
academic structure of the University, take into account the motivation of the student. Also these courses attempted to accomplish in one or two quarters what the public schools were unable to do in twelve years.

Second, the term "remedial" carries a stigma that is distasteful to "disadvantaged" students and the instructor teaching them. Typically, however, programs designed for minority populations have assumed a remedial pose. The task, whether explicit or implied, has been to somehow bring the students "up to" the level of peers in the more fortunate population; to provide a crash program to facilitate the skills denied them in their "culturally deprived" environment. This approach, in the opinion of the writer, inevitably communicates an implicit and unwarranted as sumption of student inferiority to the students enrolled, and contributes to the monumental rate of failure of the programs so designed.

In the fall of 1969 , the writer made a trip to Southern Illinois University to review their program. The experience was exciting and stimulating because SIU was experimenting with a curriculum which transcended its special concern for the skill development needs of the disadvantaged students and focused on the process of learning per se by appealing to the cultural, social, linguistic and personal values of the student. The SIU experiment provided inspiration and served as a working model for this curriculum 
experiment in the Operation PLUS program at Portland State University.

\section{THE OPERATION PLUS PROGRAM}

The Operation PLUS (Paced Learning for Urban Students) is Portland State University's special admission and support service program designed to assist students who are from low-income families and have G.P.A.'s below 2.25. Operation PLUS (formerly Project TEACH) began in 1968, and was supported by funds from the State of Oregon. In 1971, application was made to the Federal Government. Since that time approximately $\$ 53,000$ in Federal funds has been awarded PLUS each year.

The multi-racial staff is dedicated to serving the needs of all the students who meet program criteria for admission. The staff includes one Director, a secretary, a Reading and Study Skills Coordinator, two reading instructors, two counselors, a recruiter and several tutors who are upper division students at Portland State University.

Students admitted to Operation PLUS meet the following criteria:

1. The family income is below $\$ 9,000$ per year.

2. The prior Grade Point Average is less than the admissible GPA for regular student admission to Portland State 
University, 2.25, or less than 2.50. Students who have a GPA of under 2.25 are limited in number to three percent $(3 \%)$ of the previous year's total freshman enrollment at P.S.U.

3. A G.E.D. score below 55 .

4. Students transferring from another institution must have less than 45 quarter hours of credit.

Veterans and disabled or handicapped students are also admissable to the program. Three percent (3\%) of the total enrollment can be admitted at the discretion of the Program Director, with exceptions to the above criteria.

Generally speaking, students from low income families, who could benefit from the extra services of Operation PLUS, are selected for the program.

Operation PLUS provides assistance in the following areas:

1. The READING AND STUDY SKILLS PROGRAM strives to reinforce the basic skills needed for successful college experience, and is designed to provide students with the opportunity to improve their vocabularies, reading comprehension, study skills, writing skills, and reading speed. Students take one to three quarters of reading, depending on their reading level on entering into the program. Each of these reading courses receives college credits. 
2. The TUTORIAL MATH PROGRAM helps students gain the necessary basic skills in mathematics. It operates much the same as the reading program insofar as credits and placement are concerned.

3. TUTORS are provided for Operation PLUS students in classes in which they feel they are having difficulty. The Operation PLUS office has a list of tutors available in almost all a reas of study.

4. ACADEMIC COUNSELING AND ADVISING. Each student upon entry into the Operation PLUS program, is assigned an Academic Advisor to help with his schedule of class work. Much individual attention is given students to enable them to sign up for classes in which they can succeed. Operation PLUS students receive priority registration each quarter.

5. PERSONAL COUNSELING is handled by a full-time staff member. The counselor, besides helping students with personal problems, also assists them in obtaining housing while they are attending Portland State University.

6. FINANCIAL AID COUNSELING. Assistance in obtaining financial aid is provided for each student (according to individual financial needs) by the Financial Aid Counselor. Operation PLUS students qualify for regular financial aid funds, and can apply by filling out the PSU general financial 
aid application, the Confidential Statement, and the Basic Opportunity Grant Form. The Financial Aid Counselor also helps students with emergency loans, budgeting and parttime and summer employment.

7. CAREER EXPLORATION is provided for Operation PLUS students. Students are helped to develop an awareness and foundation which will enable them to make career choices through speakers, exploration, and counseling.

\section{MOTIVATION IN RELATION TO THE VALUATION OF CONCEPTS USED IN THE STUDY}

Typically, students that are educationally and economically "disadvantaged" lack the requisite motivation for academic success in college. They have neither developed the study skills nor have they had the proper orientation to academic abilities during their early school experiences. Academic work to them is an ordeal rather than interesting or exciting. Furthermore, their experiences with academic activity have revealed their own inadequacies and promoted only a sense of inferiority in relation to their middle-class counterparts. These students value themselves very low in the academic environment. For this reason, disadvantaged persons for the most part try to avoid academic activities. This fact is expressed by most academicians as "lack of motivation." This phrase is easy enough to 
use to account for the absence of a certain kind of desired behavior, but it should be pointed out that although many psychologists talk of motivation, nowhere in the literature have we seen that anyone really knows what "motivation" is. What is called "lack of motivation" may actually be the overriding presence of anxiety generated by the student's past experiences with, and expectations of, schooling. Most traditional psychological learning theories suggest that anxiety develops as a result of frustration in learning situations and blocks learning from taking place. Wolpe (1958) adopts the position that anxiety is a major causal determinant of inappropriate avoidance behavior toward learning.

In 1958, Wolpe devised a counterconditioning method called "desensitization" that proved successful in reducing anxiety and modifying emotional behavior. He stated three sets of variables essential for achieving consistent counterconditioning outcomes. First, he said it is necessary to select an anxiety-neutralizing stimulus capable of inducing a competing condition of sufficient strength to overcome the reactions ordinarily evoked by the emotionarousing cues. Second, he said that emotional responses to be counteracted are relatively weak and hence can be readily extinguished. The arousal potential of more aversive situations supposedly is progressively reduced by generalization of anxiety extinction from preceding weaker items. Through successive advances of extinction and 
generalization, stimuli of increasing aversiveness can be actually neutralized without evoking anxiety of an intensity difficult to countercondition. Third, Wolpe said the anxiety-reducing and the aversive stimuli must be contiguously associated.

The Innovative Curriculum was an attempt to treat the problem of low motivation and low value for self, as well as academic skills, by presenting students in Operation PLUS with a "meaningful" and "interesting" academic curriculum by means of an instructional methodology that is practical and conducive to getting students who previously displayed little interest in academic pursuits to make earnest efforts toward intellectual development. (See Appendix A for a description of the experimental curriculum). It was assumed that many of these students would experience a high proportion of anxiety because of previous school experiences, and also because of the more common experience of all freshmen students, who come to campus fearful of the more difficult courses and academic assignments they expect to encounter. Hence, the psychological principles of counterconditioning suggested by Wolpe were considered appropriate and were utilized in the development and instruction of the innovative curriculum.

Each of the courses was taught by a method of desensitization to treat the assumed motivational and anxiety problems of students. That is, an attempt was made to reduce the students' fear to some 
degree by having small, informal group meetings, by gradual exposure to progressively more demanding situations, by expectation that participation in the program would be a meaningful experience, and by the close relationship with instructor/counselors. The students and instructors in each class spent the first few weeks in informal settings (like a lounge and beer pub) rapping with each other about their problems with education and learning, and how these problems might be solved through participation in the new curriculum. The class shifted to a slightly more formal classroom setting the third week, with a lecture beginning on Monday, colloquium on Tuesday and Thursday, and seminar on Wednesday and Friday. These methods corresponded with the counterconditioning methods devised by Wolpe.

\section{ATTITUDE MEASUREMENT}

The concept of attitude has several differing definitions. This study was done using the Thurstone (1931) view of attitude which suggests that attitude is a relatively simple unidimensional concept, referring to the "amount of affect for or against a psychological object" (page 261). Fishbein (1967) defined beliefs and behavioral intentions independently of attitude and viewed them as indicators of attitude. He stated that the unidimensional view of attitude is the most realistic because the operations by which attitudes are measured almost invariably yield a single score that is unlikely to reflect the 
individual's differing positions in any precise fashion. Fishbein maintained that an estimate of attitude may be obtained "through a consideration of affect per se, through a consideration of beliefs and their evaluative aspects, or through a consideration of behavioral intentions and their evaluative aspects" (page 483).

Of the many available scaling methods a semantic differential was considered appropriate for this study. This scale has a high validity and it has the ability to allow accurate and relatively culturefree measurement (Osgood, 1957). According to James E. Britton, validity of the differential attitude scales appears to be high, based on high correlation with scores gathered by the traditional Thurstone, Likert and Guttman types of scales (pp. 289-295). 


\section{CHAPTER II}

PROCEDURE

METHODS - PART I

\section{Subjects}

The experiment compared two groups:

1. PLUS Innovative Curriculum Group

2. PLUS Standard Curriculum Group

Of the fifty-four students admitted to the Operation PLUS program, twenty-seven (27) randomly selected students were given the Innovative Curriculum (12 hours) with one hour of P.E. and three hours of Orientation-Study Skills Clinic, for a total of 16 hours. This group was called the PLUS Innovative Curriculum Group (PICG).

The other twenty-seven students chosen for participation in the Operation PLUS program took 12 hours of the standard lower division University course work, one hour of P.E. and the same OrientationStudy Skills course (at the same time) taken by the PICG. This group of PLUS students was called the PLUS Standard Curriculum Group (PSCG). 
A group of 54 regularly admitted entering freshmen at Portland State University was drawn on a random basis, half (27) of these were randomly selected to serve as the Regular University Curriculum Group(RUCG). Unlike PLUS's "disadvantaged" students, this group met regular University admission requirements of a minimum 2.25 GPA in high school, Also, in contrast to the PLUS student groups, this group of students had a socioeconomic status high enough to preclude their receiving financial aid from the University.

The RUCG was expected to represent a broader but higher social and economic status than the two PLUS groups, but excepting the PLUS Orientation-Study Skills clinic their curriculum experience was similar to the PLUS Standard Curriculum Group. The Regular University Group students each enrolled in at least 15 hours of regular lower-division courses offered at P.S.U. and had access to counseling services which are normally available to P.S.U. students. Because treatment and subject differences were confounded in this group it could not be compared directly with the PLUS groups in a single experimental design. However, this group was given the semantic differential test to explore the nature of the instrument used in the study - in particular to find the relations among the three scales of self-worth, academic orientation and academic skills.

The following experimental hypothesis was tested: students in the Operation PLUS Innovative Curriculum Group will show a positive 
attitude pattern, greater, as measured on a semantic differential scale, than the pattern shown by students in the PLUS Standard Curriculum.

\section{Scale Construction}

A semantic differential-type scale was constructed by obtaining 21 concepts which were divided into three broad classifications: self-worth, academic skills, and academic orientation. This classification system is shown in the table below. These particular concepts were chosen because they are considerations that all people have, at least occasionally. They are meaningful concepts, and are relevant to all the students' attitudes regarding academic skills, valuation or achievement, and self-concept.

\section{TABLE I}

\section{CONCEPTS ON THE SEMANTIC}

DIFFERENTIAL SCALE

\begin{tabular}{|c|c|c|}
\hline Self-Worth & Academic Skills & Academic Orientation \\
\hline My race & Writing papers & Teachers \\
\hline My mind & Research & 2. Books \\
\hline My life right now & Verbal arguments & 3. Science \\
\hline My family & 4. Class discussions & 4. College \\
\hline 5. Minority Groups & 5. Getting the facts & $\begin{array}{c}\text { 5. Understanding } \\
\text { Nature }\end{array}$ \\
\hline 6. My past & $\begin{array}{l}\text { 6. Speaking up in } \\
\text { class }\end{array}$ & $\begin{array}{c}\text { 6. Understanding } \\
\text { people }\end{array}$ \\
\hline 7. My future & & \\
\hline 8. My body & & \\
\hline 9. My neighborhood & & \\
\hline
\end{tabular}


The semantic differential-type scale consisted of 21 pages (because there were 21 concepts to be rated) with one concept per page. Each page consisted of 9 sub-scales with 7 response categories for each scale. Standard written instructions, similar to those suggested by Osgood with some modification (Appendix B) were developed for each subject.

In order to calibrate the attitude scale, by determining positive direction and negative direction of the scale, a group of 27 persons, ranging in age from 21 to 33, were chosen from the Portland Model Cities district (The Model Cities District is the district, Federally defined as "substandard", in the North East area of Portland, Oregon, where the highest concentration of the city's 21,000 blacks and other minority group members live) and asked to rate the 21 concepts before the beginning of the school year. It was assumed that these persons had been classified as educationally disadvantaged at one point in their lives, but had achieved educational success. They were considered successful in occupations that demand a certain level of self-confidence as well as having mastered and continued the use of certain academic skills. The test results for these individuals set the "good" end of the scale (the high-point end) as the positive direction, and the low-point end as the negative direction. For example: 


\section{BOOKS}

(Positive) Good

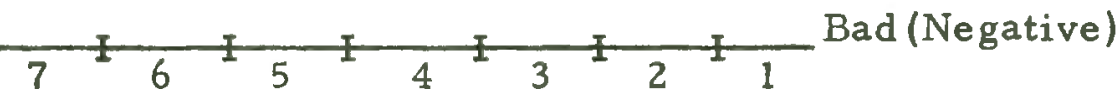

This group, then, served as the Criterion Group for the two student comparison groups who took the test at the end of the school year, in the sense that a positive pattern in attitude for each of the experimental groups was determined in reference to the pattern and direction shown by this group. These persons were also chosen to provide a closer socioeconomic parallel to PLUS students and thus introduce a communality of non-academic experiences which might minimize the influence of factors extraneous to the effects of curriculum. The socioeconomic similarity between the PLUS student population and the Criterion Group is close. Eighty percent of the PLUS students were drawn from the Model Cities District in Portland. Thus, factors influencing self-worth and academic attitudes which are generated by community experiences outside the curriculum were held as constant as possible.

\section{METHOD - PART II}

Ireatment

Treatment of the two experimental groups consisted, by definition, of subjecting each group to a different freshman curriculum experience for one academic year. Standard PLUS students we re 
enrolled in 13 credit hours of the se courses but we re also enrolled in the more personalized orientation course each term and had access to somewhat more personalized counseling and other support services. The PLUS Innovative Curriculum Group enrolled in the Innovative courses which involved individualized instruction, and these students also had access to the counseling and support services provided for the Standard Curriculum PLUS Group. At the year's end, the two experimental groups were tested on the Semantic Differential and compared with the positive pattern defined by the Criterion Group. The Regular University Curriculum Group was also tested at this time with the same instruments.

The four groups' characteristics and aspects of treatment are compared in Table II on page 22.

Procedure Used for Scoring the Semantic Differential

Each of the semantic differential tests taken by subjects in the PLUS Innovative Curriculum Group, PLUS Standard Curriculum Group and the Regular University Group was scored by taking the sum of the responses for each concept (for example, each page of the test consisted of a concept and 9 rating scales with 7 response slots to each scale. Combined, the scales allow a maximum of 63 points and a minimum of 9 points) and averaging the sum for the concepts over the concepts in a given category (self-worth, academic skills, and academic orientation). Hence, each subject had a mean score for each category. Only the means of the scores in the PLUS groups were compared by using the Hotelling's T-square (1931). 
TABLE II

COMPARISON GROUPS' CHARACTERISTICS AND ASPECTS OF TREATMENT

\begin{tabular}{|c|c|c|c|c|}
\hline & $\begin{array}{l}\text { Criterion } \\
\text { Group }\end{array}$ & $\begin{array}{l}\text { PLUS Innovative } \\
\text { Curriculum Group }\end{array}$ & $\begin{array}{l}\text { PLUS Standard } \\
\text { Curriculum Group }\end{array}$ & $\begin{array}{l}\text { Regular University } \\
\text { Curriculum Group }\end{array}$ \\
\hline Number in Group & 27 (Initially) & $27-17 *$ & $27-22 *$ & $27-19 *$ \\
\hline $\begin{array}{l}\text { Socioeconomic } \\
\text { Background }\end{array}$ & $\begin{array}{l}\text { Lower Class } \\
\text { Minority Status } \\
\text { Middle Class Econ- } \\
\text { omic }\end{array}$ & $\begin{array}{l}\text { Lower Class } \\
\text { Minority Status } \\
\text { Lower Economic }\end{array}$ & $\begin{array}{l}\text { Lower Class } \\
\text { Minority Status } \\
\text { Lower Economic }\end{array}$ & $\begin{array}{l}\text { Midd Class Status } \\
\text { Middle Economic } \\
\text { pm average }\end{array}$ \\
\hline $\begin{array}{l}\text { Hours Enrolled } \\
\text { Per Term }\end{array}$ & Not Applicable & 16 & 16 & $15+$ \\
\hline $\begin{array}{l}\text { Orientation } \\
\text { Clinic }\end{array}$ & Not Applicable & Yes & Yes & No \\
\hline PLUS Counseling & Not Applicable & Yes & Yes & No \\
\hline $\begin{array}{l}\text { University } \\
\text { Counseling } \\
\end{array}$ & Not Applicable & Access & Access & Access \\
\hline $\begin{array}{l}\text { Student-Teacher } \\
\text { Ratio }\end{array}$ & Not Applicable & $1: 9$ & & \\
\hline $\begin{array}{l}\text { Individualized } \\
\text { Instruction } \\
\text { Program } \\
\end{array}$ & Not Applicable & Yes & No & No \\
\hline
\end{tabular}

*The number of students in each group changed largely due to attrition. Two people from the Innovative Curriculum program switched to the Standard PLUS curriculum after one term and 8 people dropped out of school during the year. Seven students in the PLUS Standard Curriculum dropped out of school during the year, and 8 students in the regular university curriculum group dropped out of school during the year. 


\section{CHAPTER III}

\section{RESULTS}

The results of the analyses are shown in Tables III and IV. The difference among the two groups of means was tested for significance, using the Hotelling's $\mathrm{T}$-squared analysis. The results indicated no significant difference between the Operation PLUS Innovative Curriculum Group and the Operation PLUS Standard Curriculum Group $(F=0.90)$ on the three scales.

TABLE III

MEANS OF THE TWO GROUPS ON THE ATTITUDE SCALES

\begin{tabular}{llcc} 
GROUP & $\begin{array}{l}\text { Self }- \\
\text { Worth }\end{array}$ & $\begin{array}{c}\text { Academic } \\
\text { Orientation }\end{array}$ & $\begin{array}{c}\text { Academic } \\
\text { Skills }\end{array}$ \\
\hline
\end{tabular}

PLUS Innovative Curriculum

Group
$\mathrm{N}=17$
50.76
41.23
32.85

PLUS Standard Curriculum

Group
$N=22$
48.26
41.49
32.06

The results of the test for correlations between the measures indicate a significant correlation between the self-worth scale and the academic orientation scale, between the self-worth and academic skills scale for the Operation PLUS Innovative Curriculum Group. A 
significant correlation was shown between the self-worth and academic orientation and self-worth and academic skills scale, and between the academic orientation and academic skills scales for the PLUS Standard Curriculum Group.

A significant correlation also was shown between the academic orientation and academic skills scales for the RUCG. There was no significant correlation between the self-worth and academic orientation and self-worth and academic skills scales for the RUCG.

TABLE IV

CORRELATIONS BETWEEN MEASURES

GROUP

PLUS Innovative Curriculum

Group

$\mathrm{N}=17$

$* 0.49$

$* * 0.62$

0.40

PLUS Standard Curriculum

Group

$\mathrm{N}=22$

$* * 0.62$

$* * 0.60$

$* * 0.75$

Regular University

Curriculum Group

$$
N=19
$$

0.22

0.10

$* 0.56$

*Significant at the 0.05 level

* Significant at the 0.05 and the 0.01 levels

As an additional analysis, a test was performed to determine whether there was a significant difference between the SW-AO correlations, SW-AS correlations, and AO-AS correlations for each of the three groups. A $\mathrm{Z}$ of 1.71 was found between PLUS Innovative and Regular 
for SW-AS scales at the . 10 level of significance. Also, a $\mathrm{Z}$ of 1.75 was found between PLUS Standard and Regular group for SW-AS at the .10 level of significance. 


\section{CHAPTER IV}

\section{DISCUSSION AND CONCLUSION}

The results of this study indicate that there was no significant difference in attitude patterns between the Operation PLUS Innovative Curriculum Group and PLUS Standard Curriculum Group on the selfworth, academic orientation, and achievement scales.

The mean difference on the self-worth vector between the Innovative Curriculum Group and the Operation PLUS Standard Curriculum Group is approximately two points but the difference is not significant. One could postulate that the similarity between the se two groups is due to the general experience both groups received as a result of being in the Operation PLUS program. It is plausible that the two groups value the self-worth, academic orientation and academic achievement components similarly.

It is important to recognize that the social aspects of the Operation PLUS program may have acted to provide students with psychological and social support and influenced their attitudes about the academic skills and achievement. The question is, then: what is the effect of the social aspects on student attitudes? The data, of course, cannot provide an answer to that question. 
Both sets of PLUS students had access to personal counseling through the PLUS support service program. PLUS counselors have an opportunity for more thorough understanding of individual student backgrounds and problems than do the regular University counselors because of the smaller and more homogeneous client population of PLUS students. The PLUS program likewise allows counselors time for careful record-keeping, greater numbers of possible exposures to the students, and greater feedback from other members of the PLUS student population as to problems affecting the whole of the client group. In contrast, the Regular University Group students were entirely without either an Orientation Course oriented to teachercounseling practices, a program of deliberately supportive individualized instruction, or such counseling opportunities as PLUS provided. The counseling available to Regular University Curriculum Group students was that available through the University Counseling Center, for which they had to compete with many more students from a much more heterogeneous student/client group. Regular University Curriculum Group students might the refore be assumed to have had less opportunity for the positive enhancement of self-worth through teacher-student interaction, classroom programs for development or personal counseling services than either group of PLUS students. Also, personal expectations of University students upon entering college would vary widely between these PLUS and non-PLUS 
groups. The Regular University Curriculum Group students were accepted into college because their background and experience suggested to the Admissions Office that they were qualified for college and likely to succeed in academic enterprise.

PLUS students were chosen on the basis that they were "educationally disadvantaged" - - that is, they are students with a record of achievement which would not permit admission to college, let alone predict success in college course work. Academic success for PLUS students, therefore, has been, by definition, unexpected. There is reason to suppose that self-concept might rise for PLUS students during the first few terms of completing college course assignments. In contrast, regular University students we re admitted on the basis of having achieved academically and probably predicted their own successes on the basis used by the Admissions Office -- past experience. These freshmen, if anything, are more likely to find themselves required to work and compete more vigorously than they did during the years immediately preceding college in order to achieve satisfactory progress. The likelihood of this group experiencing pleasant surprises caused by greater achievement than previously expected is somewhat less, then, than for either group of PLUS students. Group scores on the self-concept measures very likely reflected this difference in expectations upon entering college, for merely staying in school a year is a triumph for many PLUS students while it is par 
for many University students from middle-class homes.

The larger question, however, is how much change in student attitudes was provided by the Innovative Curriculum? While the results of the experiment do not indicate any appreciable difference in attitudes between the Operation PLUS Standard Curriculum Group and the Operation PLUS Innovative Curriculum Group, one can impressionistically conclude that the Innovative Curriculum Group might have had a positive effect on the student's attitudes about academic orientation and academic skills. Otherwise, the students must have had a positive attitude about these things to start with; we know that is not in keeping with the traditional theories and experience regarding "educationally disadvantaged" students.

It is important to note that there is a significant correlation for the self-worth scale between the academic orientation and academic skills scale for the PLUS Innovative Curriculum Group and the PLUS Standard Curriculum Group. The correlation for PLUS Innovative Curriculum Group on the self-worth/academic orientation scales was significant at the .05 level which requires a correlation of 0.48 . The Innovative Curriculum Group also showed a significant correlation at both the .05 and the .01 level on the self-worth/academic skills scales which requires a correlation of 0.48 and 0.60 respectively. The correlation for PLUS Standard Curriculum Group on the self-worth/ academic orientation, self-worth/academic skills and academic 
orientation and academic skills scales was significant at both the .05 and the .01 levels which requires a correlation of .42 and .54 respectively.

The correlation for the Regular University Curriculum Group on the academic orientation and academic skills scales was significant at the 0.05 level which requires a correlation of .45 .

The correlations between SW-AO and SW-AS suggest to the writer that a lot of PLUS students' self-concept was invested in their academic achievement and skills. It is apparent that the attitude of these students about themselves and about academic achievement and skills seems to be integrated. Hypothetically, then, one could assume that as these students develop their academic skills and experience academic success their self-worth will increase. On the other hand, the Regular University Group showed comparatively little relationship between self-worth and academic achievement. This may indicate that these students' attitude about themselves and about academic achievement and skills is not integrated. These students possibly see self-worth feeling and academic abilities as two completely different things and do not relate them together significantly.

There was a significant correlation between the academic orientation scale and the academic skills scale for the Regular University Group. This suggests to the writer that if students have a 
good feeling about their academic skills, they will also have good feelings about doing academic tasks. Also, there was a significant correlation between the academic orientation scale and the academic skills scale for the PLUS Standard Curriculum Group. The students like the Regular University Group, value academic skills and academic orientation kinds of activities. It is interesting that no correlation was shown between the academic skills scale and academic orierntation scale for the PLUS Innovative Curriculum Group. This may indicate that the PLUS Innovative Curriculum Group views academic skills and academic activities as two different things. This is likely since the Innovative Curriculum did not emphasise the development of academic skills as much as the development of self-image through discussions about things involving personal worth and positive versus negative thinking.

The additional analysis was performed to indicate which correlations of SW vs AO, SW vs AS, and AO vs AS differ significantly from one group to another. The results indicate that under SW vs AS there is a significant difference between the OPICG and the RUCG. It was also determined that under the SW vs AS a significant difference was found between the PSCG and the RUCG. This could further support the notion that PLUS students on the whole integrate their attitude about self with their attitude about academic skills more than the RUCG. 
The data does not allow the writer to make any sure conclusions or solid interpretations in terms of the Operation PLUS Innovative Curriculum Group versus the Operation PLUS Standard Curriculum Group because the data does not show a significant difference between the two groups. It is possible, however, to look at these data in different ways and make certain impressionistic observations. For example, it seems that it would be possible to postualte that the Innovative Curriculum had some impact on student attitudes. Students were randomly assigned in the Innovative Curriculum and the Standard Curriculum and the refore the groups of students we re pretty well balanced in terms of attitudes at the beginning of the school year. Even though the pre-test scores of the groups could not be used, the students were randomly assigned to the groups in the beginning and it is logical to expect that students were in the same place on attitudes.

Too, it would seem possible, since the re were no statistically reliable differences in attitudes between the Innovative Curriculum Group and the PLUS Standard Curriculum Group, that both Operation PLUS groups were getting significant positive reinforcement.

The PLUS program ended the year with a 78 percent retention rate, the highest in the program's history. Nineteen (19) students who started the year in Innovative Curriculum completed successfully, and 20 students who began in the Standard Curriculum completed successfully. Since the number of students completing the school year is 
approximately equal for both groups, either the traditional academic standards are superficial, or the Innovative Curriculum program was effective. 


\section{BIBLIOGRAPHY}

Bandura, H. Principles of Behavior Modification, New York: HoltWinston, Inc., 1969, p. 222.

Berlyne, D. E. Structure and Direction in Thinking, New York: John Wiley and Sons, Inc., 1965, p. 244.

Brindon, J.E. "Deriving an Attitude Scale From Semantic Differential Data," 1961, Public Opinion Quarterly, 25:289-295.

Downie, N.S, and R.W. Heath. Basic Statistical Methods, fourth edition, Harper \& Row, 1974, pp. 225-228.

Fishbein, M. "Attitude and the Production of Behavior," In $M$.

Fishbein, ed., Readings in Attitude Theory and Measurement, New York: John Wiley and Sons, Inc., 1967.

Hotelling, H. The Generalization of Student's Ratio, and Math Statistic, Ann. Math Statis. Vol. 2, 1931, pp. 360-378.

Office of Education, Health, Education and Welfare, Alternatives to The Revolving Door, 1974.

Osgood, E.C., George J. Suci, Percy H. Tannenbaum. The Measurement of Meaning, Urbana, Illinois, University of Illinois Press, 1951.

Thurstone, L. L. "The Measurement of Social Attitudes," Journal of Abnormal and Social Psychology, 1931, 26:244-269.

Tittle, C.R. and R.J. Hill. "Attitude Measurement and Prediction of Behavior: An Evaluation of Conditions and Measurement Techniques," Sociometry, 1967, 30:(2):199-213.

Western Interstate Commission on Higher Education. Urban and Minority Centered Programs, 1969-70. 


\section{LIST OF APPENDICES}

APPENDIX

PAGE

A

Description of the Operation PLUS

Innovative Curriculum .........

36

B

Semantic Differential Test Instructions ..

40 


\section{APPENDIX A}

\section{INNOVATIVE CURRICULUM}

The Innovative Curriculum content encompassed four areas:

1. Classroom instruction

2. Student seminar discussions

3. An Orientation and Academic Skills Clinic, and

4. Field work in the community.

The content of the curriculum satisfied first year lower division requirements at Portland State University. The one-year curriculum allowed students to complete a minimum of 36 credit hours.

The curriculum was designed to develop communicative and research skills and increase general knowledge within a framework which was relevant to student experience as well as conducive to the development of positive self-concept. Student projects were not solely academic but allowed participation in community affairs in order to help the student relate his new learning to the practical requi rements of daily survival.

\section{THE ARTS AND LETTERS CURRICULUM}

The Arts and Letters Curriculum stressed communicative purpose of three kinds: "inquiry", emphasizing the use of language to perceive and explain reality; "expression", emphasizing the 
communication of emotions; and "exchange", emphasizing message construction of various discursive forms to be understood by others and subject to their response as well as formal standards. Consideration of appropriate language use was central to all three categories. Each student was required to engage in one major project each term, each project emphasizing a different communicative purpose. Each term the group was divided into three sections according to the mode of expression they had chosen to use. The major projects were shared with the entire group.

The goal of regular weekly classroom instruction and exercises was to develop knowledge, resources, skills and attitudes which would help students define and articulate what they wished to express.

The Arts and Letters staff included one full-time instructor and three student assistants.

\section{THE SCIENCE CURRICULUM}

The Science Curriculum had four goals. A body of knowledge was presented to students with the purpose not only of transmitting information but also to develop problem-solving techniques, instill scientific attitudes, and encourage the use of and continued interest in science as a way of dealing with the environment.

In a weekly lecture, general questions we re posed by the 
instructor and discussed by the class. Two groups were formed, which began to choose and study, then test, hypotheses, using not only open labs at PSU but all the urban environment as their test laboratory. Progress was monitored and support provided by small group meetings and individual discussions with the instructor and teaching as sistant.

The instructor for the Science Curriculum was assisted by one teaching assistant.

\section{THE SOCIAL SCIENCE INNOVATIVE CURRICULUM}

The goals of the Social Science Curriculum design were twofold. The students were to be shown with methods of research and analysis used in the social sciences, and an introduction to a broad spectrum of knowledge was also presented.

Rather than confine students to study within each discipline, the interrelated nature of the social science areas was stressed, in order that students might perceive the social sciences as useful perspectives for understanding daily reality rather than as a series of artificial academic categories.

In the first six weeks, students studied and discussed problems of research and evaluation in the social sciences. Each student chose a single topic for research. Students studied methods of research and were introduced to the library as they surveyed their 
chosen research topic. The students presented their research findings to the group in an integrated seminar at the end of each quarter. Each student completed 2-3 more ambitious research and report projects during the remaining academic year.

A single lecture and two small group discussions were held throughout the year on a weekly basis, to present and discuss major social science concepts.

Staff for the Social Science Curriculum consisted of one senior instructor, two teaching assistants and two student assistants. 


\section{APPENDIX B}

\section{INSTRUCTION}

The purpose of this study is to measure the meanings of certain things to various people by having them judge them against a series of descriptive scales. In taking this test, please make your judgments on the basis of what these things mean to you. On each page of this booklet you will find a different concept to be judged and beneath it a set of scales. You are to rate the concept on each of these scales in order.

Here is how you are to use these scales:

If you feel that the concept at the top of the page is very closely related to one end of the scale, you should place your check-mark as follows -

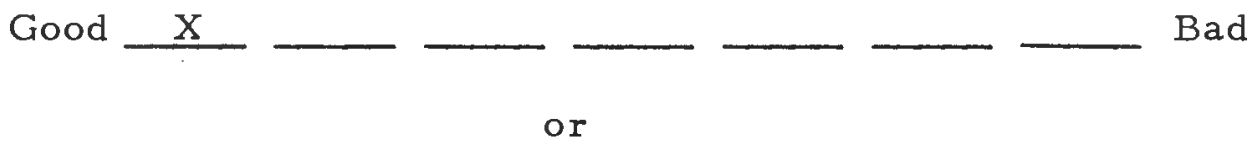

Good

$$
\mathrm{X}
$$

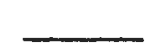
Bad

If you feel that the concept is quite closely related to one or the other end of the scale (but not extremely), you should place your check-mark as follows:

Kind
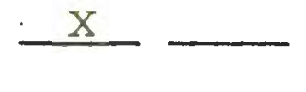

or

Kind
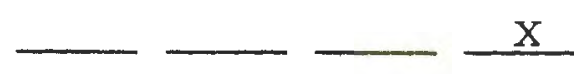
Cruel 
If the concept seems only slightly related to one side as opposed to the other side (but is not really neutral), then you should check as follows:

Beautiful

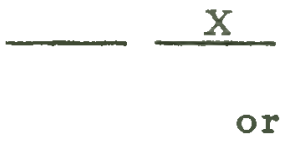

Beautiful

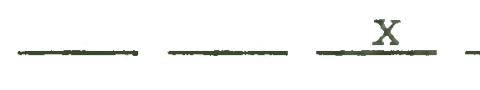

Ugly

The direction toward which you check, of course, depends upon which of the two ends of the scale seem most characteristic of the thing you a re judging.

If you consider the concept to be neutral on the scale, both sides of the scale equally associated with the concept, or if the scale is completely irrelevant, unrelated to the concept, then you should place your check-mark in the middle space. However, think carefully about each scale before you decide it is irrelevant, or that it is neutral.

Sharp $\mathrm{X}$ Dull

IMPORTANT: (1) Place your check-mark in the middle spaces, not on the boundaries:

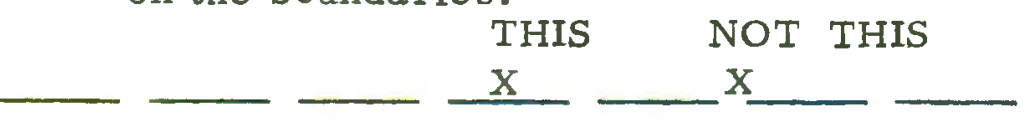

(2) Be sure you check every scale for every concept do not omit any

(3) Never put more than one check-make on a single scale 
Sometimes you may feel as though you've had the same item before on the test. This will not be the case, so do not look back and forth through the items. Do not try to remember how you checked similar items earlier in the test. Make each item a separate and independent judgment. Work at fairly high speed through this test. Do not worry or puzzle over individual items. It is your first impressions, the immediate "feelings" about the items, that is wanted. On the other hand, please do not be careless, because we want your true impressions. 